\title{
Monika Guszkowska
}

Zakład Psychologii, Akademia Wychowania Fizycznego

Józefa Piłsudskiego w Warszawie

\section{Czynniki warunkujące stany emocjonalne kobiet ciężarnych uczestniczących w zajęciach ruchowych*}

\section{Wprowadzenie}

Podczas ciąży i w okresie poporodowym u znacznej liczby kobiet występują znaczące wahania nastroju, w wielu przypadkach spełniające kryteria zaburzeń afektywnych. Wyniki badań sugerują, że wskaźniki depresji u ciężarnych mogą być nawet wyższe niż w okresie połogu (D a C o sta i in., 2000; Evans i in., 2001; J o s e f s o n i in., 2001; F i eld i in., 2003), a wysokie wskaźniki depresji w czasie ciąży są zwykle zapowiedzią depresji poporodowej (O'Hara i in., 1984).

Podczas ciąży istotnie nasila się znużenie, obniża zaś poziom wigoru, zarówno z powodów fizjologicznych, jak i psychologicznych (Ch o u i in., 2003). Przyczynia się to do pogarszania samopoczucia kobiet ciężarnych, gdyż zmęczenie podczas ciąży jest istotnie skorelowane ze wskaźnikami depresji i lęku (C hou i in., 2003; P oud evigne, O'Connor, 2005).

$\mathrm{W}$ ostatnim trymestrze wiele ciężarnych ujawnia wyższy od przeciętnej poziom neurotyczności (S i p iń s k i i in., 1993), co wiąże się z większą chwiejnością emocjonalną i skłonnością do przeżywania lęku i doświadczania nastrojów negatywnych. U ciężarnych obserwuje się niepokój związany z możliwością poronienia czy nieprawidłowościami w rozwoju dziecka (L e ifer, 1977). Poziom lęku stabilizuje się w drugim trymestrze (Leifer, 1977; P ower, P a rke, 1984), niepokoje ostatniego trymestru dotyczą zwykle zdrowia dziecka i przebiegu porodu oraz stanu noworodka (L e ifer, 1977; P ower, Parke, 1984; Fleming, Corter, 1988). Wzrost poziomu lęku może wiązać się z obniżającymi samoocenę zmianami w sferze fizycznej (Moore, 1978). Kobiety ciężarne odczuwają także lęk przed porodem, perspektywa porodu jest bowiem dla wielu kobiet przyczyną silnego stresu. Jego poziom zależny jest od wieku i wielokrotności ciąży.

* Badania realizowane w ramach projektu NN 404 017838: „Aktywność ruchowa kobiet ciężarnych a stan ich zdrowia psychicznego i fizycznego oraz przebieg ciąży i porodu" finansowanego przez MNiSzW. 
Badania realizowane w populacji ogólnej potwierdzają korzystny wpływ ćwiczeń fizycznych na stany emocjonalne, niezależnie od płci i wieku, zarówno osób zdrowych, jak i cierpiących na zaburzenia natury psychicznej i somatycznej. Niewiele takich badań realizowano w populacji kobiet ciężarnych. U ciężarnych uczestniczących $\mathrm{w}$ programie ćwiczeń fizycznych o charakterze tlenowym stwierdzono znacząco niższe wskaźniki zmęczenia niż u kobiet niećwiczących (W a lla ce i in., 1986). Ciężarne aktywne fizycznie ujawniały mniej symptomów lęku, ale nie depresji, w porównaniu z kobietami niećwiczącymi w czasie ciąży (G o o d w in i in., 2000). Stwierdzono stały związek między utrzymywaniem dobrostanu psychicznego i aktywnością fizyczną w czasie wolnym, szczególnie podczas pierwszego i drugiego trymestru ciąży ( $\mathrm{D}$ a C o st a i in., 2003). W badaniach M. S. P o u d e vig ne i P. J. O'C on nor a (2005) nie potwierdzono natomiast związków między poziomem lęku i depresji w kolejnych tygodniach drugiego i trzeciego trymestru ciąży a poziomem aktywności fizycznej. W badaniach własnych (Guszkow ska, 2011) u ciężarnych uczestniczących w grupowych ćwiczeniach fizycznych przygotowujących do porodu zanotowano lepszy nastrój wyrażający się wyższym poziomem pozytywnych stanów emocjonalnych i niższym poziomem stanów negatywnych.

U ciężarnych podejmujących ćwiczenia fizyczne cztery razy w tygodniu stwierdzono najmniej symptomów depresji w czasie drugiego trymestru ciąży oraz największe zadowolenie $\mathrm{z}$ ciała $\mathrm{w}$ porównaniu $\mathrm{z}$ kobietami ćwiczącymi jedynie raz $\mathrm{w}$ tygodniu oraz nieaktywnymi fizycznie. Spadek symptomów depresji stwierdzono u ciężarnych nastolatek uczestniczących w zajęciach aerobiku (K o n i a k-G ri ffi in, 1994).

Badania nad związkiem aktywności fizycznej $\mathrm{z}$ depresją poporodową (Abraham i in., 2001) wykazały, iż kobiety biorące udział w zajęciach ruchowych już we wczesnym stadium ciąży mają znacznie niższy poziom depresji oraz ujawniają niższy poziom stresu w okresie poporodowym.

Niewiele jest też studiów nad wpływem jednorazowych ćwiczeń fizycznych na stany emocjonalne kobiet ciężarnych. Po jednorazowych ćwiczeniach fizycznych o charakterze tlenowym zanotowano u ciężarnych istotny spadek wskaźników depresji i lęku (Kolty n, 1994). Podobne efekty w postaci spadku poziomu lęku i depresji oraz wzrostu poziomu wigoru i poprawy nastroju obserwowano u kobiet $\mathrm{w}$ okresie poporodowym uczestniczących w 60-minutowej sesji ćwiczeń tlenowych o umiarkowanej intensywności (Koltyn, S c hult e s, 1997). Badania ciężarnych, biorących udział w zajęciach aquaaerobiku, wskazują, iż ćwiczenia te powodują wzrost poziomu nastrojów pozytywnych, lepsze samopoczucie, spadek poziomu emocji negatywnych oraz redukcję zmęczenia i znużenia (L ox, Tre a sure, 2000). C. L. L ox i D. C. Tre a sure (2000) wykazali zarówno spadek poziomu stresu u kobiet ciężarnych po jednorazowych zajęciach w wodzie, jak i efekty długoterminowe obserwowane po 6 tygodniach systematycznych ćwiczeń. Po jednorazowych ćwiczeniach 
programu „Aktywne 9 miesięcy” zaobserwowano u ciężarnych korzystne zmiany w sferze emocjonalnej wyrażające się zwłaszcza spadkiem poziomu lęku i napięcia (Gu s zkow ska, B e rnatek, 2010).

Wyniki wstępnych badań sugerują, że ćwiczenia fizyczne mogą przyczyniać się do zmniejszenia lęku przed porodem (Dudziak, 2008). Wyniki badań własnych (Guszkowska, Dudziak, 2008) wskazuja, że kobiety aktywne ruchowo w okresie ciąży odczuwają słabszy lęk w sytuacji wyobrażonego porodu i są silniej przekonane o tym, że ból, który będą odczuwać podczas porodu, będzie pozostawać pod ich kontrolą, ujawniają ponadto znacząco lepszy nastrój. Wyniki badań M. Płaczkiewicz (2008) potwierdzają wyższy poziom stanu lęku związanego $\mathrm{z}$ porodem u kobiet nieaktywnych ruchowo. $\mathrm{W}$ innych badaniach własnych stwierdzono niższy poziom lęku $\mathrm{w}$ sytuacji wyobrażonego porodu u kobiet uczestniczących $\mathrm{w}$ zajęciach ruchowych dla kobiet ciężarnych (G u s z k o w s k a, 2011). Także zajęcia szkoły rodzenia moga przyczyniać się do obniżania lęku przed porodem (S t a n g e r t i in., 2009).

Regularna aktywność fizyczna przyczynia się do utrzymania zdrowia fizycznego i psychicznego w każdym etapie życia. Negatywne konsekwencje braku aktywności mogą być szczególnym problemem u kobiet ciężarnych, gdyż znaczna ich część jest nieaktywna fizycznie podczas ciąży. Współcześnie zaleca się, by w przypadku braku komplikacji w przebiegu ciąży i czynników ryzyka przyszłe mamy podejmowały trwającą co najmniej 30 minut umiarkowanie intensywną aktywność fizyczną, głównie o charakterze tlenowym, przez większość dni w tygodniu, a nawet codziennie (Artal, O'Toole, 2003; D a vi e s i in., 2003; Royal College..., 2006).

Pomimo ogólnego obniżania się aktywności fizycznej w okresie ciąży niektóre ciężarne, szczególnie te, które prowadziły wcześniej aktywny tryb życia, nie rezygnują $\mathrm{w}$ tym okresie $\mathrm{z}$ ćwiczeń fizycznych, dostosowuja jedynie ich formę $\mathrm{i}$ intensywność do swojego stanu, uczestnicząc w specjalnych zajęciach ruchowych. Z myślą o kobietach oczekujących dziecka powstał program „Aktywne 9 miesięcy” przygotowany przez Katarzynę Sempolską, obejmujący ćwiczenia pilates, bodyball, jogi, TBC oraz elementy treningu relaksacyjnego i ćwiczenia oddechowe. Zajęcia te nie różnią się znacząco od typowych ćwiczeń fitness - realizowane są w formie zajęć grupowych $\mathrm{z}$ wykorzystaniem odpowiednio dobranej muzyki oraz przyborów i przyrządów. Mają one na celu poprawę ogólnej kondycji ćwiczących ze szczególnym uwzględnieniem łagodzenia bólu pleców, wyrobienia siły, zwiększenia ruchomości w stawach biodrowych, wyrobienia elastyczności mięśni brzucha oraz zmniejszenia kurczliwości mięśni. Ćwiczące uczą się rozróżniać napięcie i rozluźnienie w poszczególnych partiach mięśniowych oraz właściwie oddychać.

Celem prezentowanych badań pilotażowych było określenie wpływu jednorazowych ćwiczeń fizycznych na stany emocjonalne kobiet ciężarnych. Poszukiwano także czynników warunkujących stopień poprawy samopoczucia kobiet 
ciężarnych po zajęciach ruchowych. Przedmiotem zainteresowania uczyniono tu wybrane cechy osobowości (uwzględnione w modelu Wielkiej Piątki: dyspozycyjny optymizm, cecha lęku), stan zdrowia psychicznego oraz zmienne demograficzno-społeczne (wiek, stan cywilny, trymestr ciąży, liczba dzieci, praca zawodowa, sytuacja materialna).

\section{Osoby badane}

Badaniami objęto 25 kobiet $\mathrm{w}$ wieku od 22 do 36 lat $(M=30,00 ; S D=$ $3,571)$ w drugim $(n=9)$ i trzecim $(n=16)$ trymestrze ciąży. Kryterium włączenia do grupy był brak wcześniejszych poronień i porodów przedwczesnych, prawidłowy przebieg ciąży oraz zgoda lekarza-ginekologa na udział w zajęciach fizycznych dla kobiet ciężarnych. Wszystkie badane miały wykształcenie wyższe; 20 pozostawało w związku małżeńskim, 5 było stanu wolnego; ponad połowa badanych $(n=14)$ w czasie ciąży nie pracowała zawodowo. Jedna ciężarna miała jedno dziecko, dwie badane - dwoje dzieci, pozostałe badane były w pierwszej ciąży. Jako aktywne fizycznie przed ciążą określiło się ponad dwie trzecie badanych $(n=17)$.

Badane uczestniczyły przez dwa miesiące dwa razy w tygodniu w trwających 50 minut zajęciach ruchowych dla kobiet ciężarnych „Aktywne 9 miesięcy". Do analiz włączono tylko dane osób, które uczestniczyły w co najmniej $75 \%$ zajęć.

\section{Narzędzia badawcze}

Do diagnozy stanów emocjonalnych zastosowano Inwentarz Stanu i Cechy Lęku Spielbergera (ISCL), w polskiej adaptacji W. Wr ze śn i e w s k i e g o i in. (2002), Przymiotnikową Skalę Nastroju (UMACL) Matthewsa, Chamberlaina i Jonesa w adaptacji E. Goryńskiej (2005) diagnozującą trzy wymiary nastroju (ton hedonistyczny, pobudzenie energetyczne i pobudzenie napięciowe) oraz Profil Nastrojów McNaira, Lorra i Dropplemana (Profile of Mood States POMS) w polskiej adaptacji B. D u dk a i J. K o n i ark a (1987), który określa nasilenie siedmiu stanów emocjonalnych, w tym pięciu pozytywnych (gniew, napięcie, zakłopotanie, przygnębienie, znużenie) oraz dwóch negatywnych (wigor i życzliwość). Pomiaru stanów emocjonalnych dokonywano bezpośrednio przed i po zajęciach ruchowych.

Ponadto wykorzystano Skalę Lęku przed Porodem w opracowaniu własnym. Skala powstała na bazie kwestionariusza ISCL w celu określenia nasilenia lęku przed porodem. Tworzy ją 14 stwierdzeń dotyczących odczuć związanych 
z porodem, zarówno wskazujących na obawy z nim związane (7 stwierdzeń, np. „Martwię się, czy podczas porodu nie stanie się coś złego mnie i mojemu dziecku”), jak i ich brak (7 stwierdzeń, np. „Gdy wyobrażam sobie poród, czuję się bezpiecznie"). Zastosowano czteropunktowy format odpowiedzi (od: 1 „zdecydowanie nie”, do: 4 - „zdecydowanie tak”). Wersją pierwotną skali przebadano 56 kobiet ciężarnych. Określono moc dyskryminacyjną poszczególnych pozycji, która waha się od 0,565 („Gdy myślę o porodzie, jest mi przyjemnie”) do 0,900 („Czuję się roztrzęsiona, gdy myślę, co mnie czeka”) i może być uznana za dobra. Rzetelność narzędzia jest w pełni satysfakcjonująca ( $\alpha$-Cronbacha wynosi 0,922$)$. Ogólny wynik testu koreluje istotnie z wynikiem w skali cechy lęku kwestionariusza ISCL $(r=0,553 ; p<0,001)$, co można uznać za wskaźnik trafności narzędzia.

W celu określenia czynników warunkujących stany emocjonalne zastosowano Inwentarz Osobowości NEO-FFI Costy i McCrae'a w polskiej adaptacji B. Zawadzkiego i in. (1998), Kwestionariusz Ogólnego Stanu Zdrowia GHQ-28 Goldberga w polskiej adaptacji Z. Makowskiej i D. Merecz (2001) służący do oceny zdrowia psychicznego w czterech wymiarach: symptomy somatyczne; niepokój, bezsenność; zaburzenia funkcjonowania i symptomy depresji oraz Test Orientacji Życiowej LOT-R Scheiera, Carvera i Bridgesa w polskiej adaptacji R. Poprawy i Z. Juczyńskiego do diagnozy dyspozycyjnego optymizmu (J u c z y ń s k i, 2001).

Dla celów badania opracowano ankietę dotyczącą historii ginekologiczno-położniczej, sytuacji rodzinnej i aktywności ruchowej. Zawierała ona pytania dotyczące przebiegu ciąży, samooceny stanu zdrowia i sprawności fizycznej, podejmowanej obecnie i przed ciążą aktywności fizycznej i zawodowej, stanu cywilnego, wsparcia ze strony partnera, liczby dzieci w rodzinie oraz sytuacji materialnej, a także planowanego porodu.

Wszystkie kwestionariusze psychologiczne cechują dobre właściwości psychometryczne (wysoka rzetelność i trafność).

Projekt został zaakceptowany przez Senacką Komisję Etyki Akademii Wychowania Fizycznego Józefa Piłsudskiego w Warszawie.

\section{Wyniki}

Poprzez badania zmierzano do określenia zmian w stanach emocjonalnych kobiet ciężarnych po jednorazowych ćwiczeniach fizycznych. W tab. 1 przedstawiono wyniki pomiaru stanów emocjonalnych bezpośrednio przed i po zajęciach ruchowych programu „Aktywne 9 miesięcy”. W celu określenia istotności różnic między pomiarami zastosowano test $t$-Studenta dla prób zależnych, zaś w przypadku zmiennych niespełniających kryterium rozkładu normalnego (podskale POMS) - test znaków rangowanych Wilcoxona. Zaob- 
serwowano istotny spadek poziomu: stanu lęku; pobudzenia napięciowego; gniewu, zakłopotania i przygnębienia. Zmiany napięcia osiagają poziom tendencji. Po ćwiczeniach fizycznych istotnie wzrósł poziom tonu hedonistycznego, zmiany pobudzenia energetycznego oraz wigoru utrzymują się na poziomie tendencji. Nie stwierdzono istotnych zmian znużenia i życzliwości. Wyniki badań wskazują więc na poprawę samopoczucia kobiet ciężarnych po jednorazowych ćwiczeniach fizycznych.

T a b e la 1

Zmiany stanów emocjonalnych po jednorazowych ćwiczeniach fizycznych

\begin{tabular}{|l|c|c|c|c|c|c|}
\hline \multirow{2}{*}{ Stan } & \multicolumn{5}{c|}{ Pomiar } \\
\cline { 2 - 7 } & \multicolumn{2}{|c|}{ przed zajęciami } & \multicolumn{2}{c|}{ po zajęciach } & \multicolumn{2}{c|}{$\begin{array}{c}\text { test } t \text {-Studenta/test } \\
\text { znaków Wilcoxona }\end{array}$} \\
\cline { 2 - 7 } & $M$ & $S D$ & $M$ & $S D$ & $t / Z^{a}$ & $p$ \\
\hline Lęk & 32,36 & 8,271 & 27,84 & 6,342 & 3,674 & 0,001 \\
\hline Ton hedonistyczny & 34,40 & 4,481 & 35,72 & 3,857 & 2,663 & 0,014 \\
\hline Pobudzenie energetyczne & 32,32 & 5,250 & 33,68 & 4,589 & 1,964 & 0,061 \\
\hline Pobudzenie napięciowe & 14,24 & 3,711 & 12,72 & 3,323 & 2,960 & 0,007 \\
\hline Gniew & 4,38 & 5,867 & 1,92 & 4,652 & $2,384^{*}$ & 0,017 \\
\hline Zakłopotanie & 5,50 & 3,822 & 3,88 & 3,468 & $2,496^{*}$ & 0,013 \\
\hline Przygnębienie & 5,13 & 8,147 & 2,54 & 6,318 & $2,084^{*}$ & 0,037 \\
\hline Znużenie & 4,58 & 4,727 & 4,08 & 4,452 & $0,734^{*}$ & 0,463 \\
\hline Napięcie & 4,92 & 4,323 & 3,83 & 5,053 & $1,890^{*}$ & 0,059 \\
\hline Wigor & 19,83 & 4,469 & 21,33 & 4,156 & $1,795^{*}$ & 0,073 \\
\hline Życzliwość & 19,70 & 3,444 & 20,09 & 3,884 & 0,488 & 0,625 \\
\hline
\end{tabular}

${ }^{a}$ Ze względu na niespełnienie wymogów normalności rozkładu zastosowano test znaków rangowanych Wilcoxona.

Przed przystąpieniem do dalszych analiz obliczono wskaźniki spadku stanów negatywnych, odejmując od wyniku pierwszego pomiaru wynik pomiaru po ćwiczeniach fizycznych oraz wskaźniki wzrostu pozytywnych stanów emocjonalnych (różnica drugiego i pierwszego pomiaru). Następnie za pomocą analizy regresji metodą krokową ustalono predyktory zmiany stanów emocjonalnych. Do równania każdorazowo jako czynniki wymiary osobowości $\mathrm{z}$ modelu Wielkiej Piątki wprowadzano: cechę lęku, dyspozycyjny optymizm, wskaźniki demograficzno-społeczne (wiek; stan cywilny: 1 - mężatka, 2 - wolna; liczba dzieci; sytuacja materialna; praca zawodowa), wskaźniki zdrowia (samoocena zdrowia, niepokój, bezsenność; zaburzenia funkcjonowania i symptomy depresji) oraz trymestr ciąży.

Spadek stanu lęku po ćwiczeniach fizycznych w niemal 70\% (skorygowane $\left.R^{2}=0,697\right)$ wyjaśnia samoocena stanu zdrowia $(\beta=0,484)$, trymestr ciąży 
( $\beta=-0,690)$ oraz sumienność $(\beta=0,459)$. Większego efektu antylękowego można oczekiwać u ciężarnych $\mathrm{w}$ drugim trymestrze, wyżej oceniających swój stan zdrowia i bardziej sumiennych.

Analiza regresji doprowadziła do wydzielenia 6 czynników determinujących łącznie w 95\% (skorygowane $R^{2}=0,951$ ) spadek pobudzenia napięciowego. Predyktory pozytywne to bezsenność $(\beta=1,324)$, otwartość na nowe doświadczenia $(\beta=0,980)$ oraz samoocena sprawności fizycznej $(\beta=0,314)$. Predyktory negatywne to wiek $(\beta=-0,507)$, neurotyczność $(\beta=-0,570)$ i niepokój mierzony GHQ-28 $(\beta=-0,747)$. Większego spadku pobudzenia napięciowego można więc oczekiwać u młodszych ciężarnych, mniej neurotycznych i ujawniających niższy poziom niepokoju, natomiast bardziej otwartych na nowe doświadczenia, mających większe trudności ze snem, ale wyżej oceniających swoją sprawność fizyczną.

Stopień spadku gniewu zależy od nasilenia niepokoju $(\beta=-0,361)$ i depresji $(\beta=-0,834)$ mierzonych kwestionariuszem GHQ-28 oraz od trymestru ciaży $(\beta=-1,361)$. Jest on większy u ciężarnych będących w mniej zaawansowanej ciąży i ujawniających mniej objawów niepokoju i depresji. Trzy predyktory wyjaśniają spadek gniewu w ponad $80 \%$ (skorygowane $R^{2}=0,826$ ).

Spadek napięcia po ćwiczeniach fizycznych zależny jest w $60 \%$ od aktywności zawodowej. U kobiet niepracujących w czasie ciąży można oczekiwać większych zmian pozytywnych $(\beta=-0,798)$.

Jedynym predyktorem spadku zakłopotania jest trymestr ciąży $(\beta=-0,695)$, który wyjaśnia ponad $40 \%$ zmienności tego wskaźnika (skorygowane $R^{2}=0,432$ ), spadek zakłopotania prawdopodobnie będzie lepiej widoczny u kobiet $\mathrm{w}$ mniej zaawansowanej ciąży. W przypadku spadku przygnębienia jedynym predyktorem okazuje się sprawność fizyczna $(\beta=0,739)$ wyjaśniająca spadek przygnębienia w 50\%. U bardziej sprawnych fizycznie ciężarnych można oczekiwać po ćwiczeniach większego spadku przygnębienia.

Spadek znużenia po zajęciach ruchowych zależy od otwartości na nowe doświadczenia $(\beta=0,512)$ i zaburzeń przystosowania $(\beta=0,876)$. Większych korzyści $\mathrm{w}$ tej sferze można oczekiwać u kobiet bardziej otwartych na nowe doświadczenia, a równocześnie zdradzających więcej symptomów zaburzeń przystosowania. Oba czynniki wyjaśniają spadek znużenia w ponad $60 \%$ (skorygowane $R^{2}=0,617$ ).

Ustalono dwa predyktory wzrostu tonu hedonistycznego: sumienność $(\beta=0,994)$ oraz cechę lęku $(\beta=0,675)$, które pozwalają przewidywać wzrost tonu hedonistycznego w niespełna $60 \%$ (skorygowane $R^{2}=0,597$ ). Należy oczekiwać, że u ciężarnych bardziej sumiennych i skłonnych do reagowania lękiem nastapi większy wzrost tonu hedonistycznego po zajęciach ruchowych. Wzrost życzliwości można przewidzieć w ponad $65 \%$ (skorygowane $R^{2}=0,654$ ) na podstawie samooceny stanu zdrowia $(\beta=0,828)$ i jest to predyktor pozytywny. Żaden z wprowadzonych do równania czynników nie pozwala przewidywać wzrostu pobudzenia napięciowego ani poziomu wigoru. 
Jako predyktor zmiany stanów emocjonalnych najczęściej występuje trymestr ciąży pozwalający przewidzieć spadek stanu lęku, gniewu i zakłopotania. Wśród cech osobowości sumienność jest dodatnim predyktorem zmiany dwóch wskaźników (spadku stanu lęku i wzrostu tonu hedonistycznego), otwartość na nowe doświadczenia pełni taką funkcję $\mathrm{w}$ odniesieniu do spadku pobudzenia napięciowego i znużenia. Wysoka samoocena sprawności fizycznej pozwala oczekiwać dużego spadku pobudzenia napięciowego i przygnębienia, zaś wysoka samoocena stanu zdrowia - dużego spadku stanu lęku i wzrostu życzliwości. Pozostałe zmienne (wiek, aktywność zawodowa, bezsenność, niepokój, zaburzenia przystosowania, depresja, cecha lęku oraz neurotyczność) pełnią funkcje predyktorów jednego wskaźnika zmiany stanu emocjonalnego.

Lęk przed porodem koreluje dodatnio z cechą lęku $(r=0,591 ; p=0,025)$ i ujemnie $\mathrm{z}$ sytuacją materialną $(r=-0,485 ; p=0,048)$. Ujemny związek $\mathrm{z}$ ugodowością $(r=-0,421)$ utrzymuje się na poziomie tendencji $(p=0,082)$.

Poszukiwano także predyktorów lęku przed porodem wśród opisanych wyżej czynników. Lęk przed porodem można przewidzieć w niemal 50\% (skorygowane $\left.R^{2}=0,486\right)$ na podstawie stanu cywilnego $(\beta=0,672)$ oraz trymestru ciąży $(\beta=-0,508)$. Silniejszego lęku przed porodem należy oczekiwać u kobiet stanu wolnego i w drugim trymestrze ciąży.

\section{Dyskusja}

Wyniki badań potwierdzają wcześniejsze obserwacje, że już jednorazowe ćwiczenia fizyczne mogą przyczynić się do poprawy samopoczucia psychicznego kobiet ciężarnych (Guszkowska, Bernatek, 2010; Kolty n, 1994; Lox, Treasure, 2000). Po trwających 50 minut zajęciach realizowanych w ramach programu „Aktywne 9 miesięcy” nastapił znaczący spadek poziomu negatywnych stanów emocjonalnych (lęku, pobudzenia napięciowego, gniewu, przygnębienia i zakłopotania). Ponieważ skala pobudzenia napięciowego diagnozuje także napięcie o charakterze lękowym, można uznać, że efekt antylękowy jest nieco silniejszy niż działanie antydepresyjne. Te rezultaty są zbieżne z wynikami badań A. G o o d w in a i in. (2000), w których u ćwiczących ciężarnych, w porównaniu $\mathrm{z}$ niećwiczącymi, stwierdzono mniej symptomów lęku, ale nie depresji. Na podstawie referowanych wyników nie można rozstrzygnąć, czy mamy tu do czynienia z bardziej ogólną prawidłowością, czy też efektem zależnym od rodzaju ćwiczeń realizowanych na zajęciach, w trakcie których monitorowano efekty ostre. Konieczne jest porównanie efektów zajęć o różnym programie szczegółowym.

Po jednorazowych ćwiczeniach fizycznych nieco podniósł się poziom energetyczny ciężarnych (zmiany pobudzenia energetycznego i wigoru osiagnęły jedynie poziom tendencji). Te zmiany wydają się korzystne w obliczu narastają- 
cego w czasie ciąży zmęczenia i znużenia (Chou i in., 2003). Co prawda nie zanotowano obserwowanego wcześniej (Guszkowska, B ernatek, 2010) bezpośredniego efektu w postaci spadku znużenia, ale może to wynikać $\mathrm{z}$ faktu, że ćwiczenia fizyczne w trakcie ich realizacji mogą być dla ciężarnych, zwłaszcza w trzecim trymestrze ciąży, męczące.

Głównym czynnikiem warunkującym wielkość efektu ostrego, czyli stopień poprawy samopoczucia po ćwiczeniach fizycznych jest trymestr ciąży. Większych korzyści emocjonalnych możemy oczekiwać u ciężarnych $\mathrm{w}$ drugim trymestrze. $Z$ badań dotyczących związków między samopoczuciem a stopniem zaawansowania ciąży wynika, że negatywne stany emocjonalne nasilają się w kolejnych tygodniach ciąży (Chou i in., 2003; DaCosta i in., 2000; Poudevigne, O'Connor, 2005). Można podejrzewać, że w ostatnim trymestrze ciąży nasilenie negatywnych stanów emocjonalnych jest na tyle duże, że ćwiczenia fizyczne wymagające wydatkowania energii i wysiłku, o które coraz trudniej wskutek zmian natury fizycznej, poprawiają je w mniejszym stopniu.

Wśród cech osobowości zaznacza się znaczenie sumienności i otwartości na nowe doświadczenia, obie cechy nasilają korzyści emocjonalne. Należy podkreślić, że predyktory zmian są zróżnicowane $\mathrm{w}$ zależności od treści stanów emocjonalnych. We wcześniejszych badaniach (Gu s zkow ska, B e rnatek, 2010) także obserwowano zależności między zmianą stanów emocjonalnych, mierzonych POMS i ISCL u kobiet ciężarnych po jednorazowych ćwiczeniach fizycznych, a ich cechami osobowości. Najczęstszym dodatnim predyktorem zmian świadczących o poprawie samopoczucia ciężarnych była cecha lęku, wśród cech z modelu Wielkiej Piątki potwierdzono (podobnie jak obecnie) znaczenie ekstrawersji i sumienności jako predyktorów dodatnich.

Znaczenie neurotyczności i otwartości na nowe doświadczenia w świetle wyników obu badań nie jest w pełni jasne. W obecnych badaniach neurotyczność jest predyktorem ujemnym spadku pobudzenia napięciowego, w badaniach wcześniejszych pełniła funkcję dodatniego predyktora wobec wzrostu wigoru. Otwartość na nowe doświadczenia w badaniach wcześniejszych stanowiła ujemny predyktor spadku gniewu, natomiast dodatni - wzrostu wigoru. Obecne rezultaty potwierdzają ten drugi wynik - zgodnie z nimi u ciężarnych bardziej otwartych na nowe doświadczenia należy oczekiwać większego spadku pobudzenia napięciowego oraz znużenia. Kwestie osobowościowych determinant wpływu jednorazowych ćwiczeń fizycznych na stany emocjonalne kobiet ciężarnych wymagają dalszych badań.

Należy zauważyć, że uwzględnienie czynników pozaosobowościowych (stan zdrowia, zmienne demograficzne) znacząco zwiększa zakres przewidywanej zmienności wskaźników zmiany stanów emocjonalnych. W badaniach uwzględniających jako potencjalne predyktory jedynie cechy z modelu Wielkiej Piątki i cechę lęku (Guszkowska, Bernatek, 2010) modele wyjaśniały 
zmienne zależne w umiarkowanym stopniu (od niespełna 20 do niespełna 50\%). W obecnych badaniach wartości $R^{2}$ mieszczą się w przedziale od 0,432 , w przypadku spadku zakłopotania, do 0,951 , w przypadku spadku pobudzenia napięciowego.

Trymestr ciąży jest natomiast negatywnym predyktorem lęku przed porodem. Podobne zależności uzyskano we wcześniejszych badaniach własnych lęk w sytuacji wyobrażonego porodu był silniejszy w drugim niż trzecim trymestrze, trymestr ciąży okazał się także negatywnym predyktorem lęku przed porodem (Gu s zk ow sk a, 2011). Dlaczego (chyba wbrew intuicji) u kobiet w bardziej zaawansowanej ciąży należy oczekiwać słabszego lęku przed porodem? Być może miały one więcej czasu na psychiczne przygotowanie się do porodu, dłużej także doświadczały różnych dolegliwości związanych z ciążą, traktują więc rozwiązanie jako swoiste wyzwolenie od uciążliwości i moment spotkania z długo oczekiwanym dzieckiem, a nie źródło negatywnych doznań.

$\mathrm{Z}$ kolei przewidywany brak wsparcia ze strony partnera $\mathrm{w}$ trakcie porodu i po narodzeniu dziecka prawdopodobnie nasila lęk przed porodem u kobiet stanu wolnego. Należy jednak pamiętać, że stan wolny nie jest równoznaczny z byciem samotną matką, obecnie wiele par żyje w związkach niesformalizowanych. $\mathrm{W}$ takim przypadku ciężarne niezamężne mogą otrzymywać takie samo wsparcie ze strony partnera, jak mężatki ze strony męża.

Prezentowane badania mają dość istotne ograniczenia metodologiczne, co znacząco redukuje możliwość generalizacji uzyskanych wyników. Po pierwsze, były realizowane $\mathrm{w}$ warunkach naturalnych i mają jedynie charakter quasieksperymentalny (plan jednogrupowy $\mathrm{z}$ pretestem $\mathrm{i}$ posttestem zmiennych zależnych). Nie stworzono grupy kontrolnej kobiet ciężarnych, które uczestniczyły w innej formie zajęć grupowych. Liczebność badanej grupa była nieduża, choć i tak względnie większa niż we wcześniejszych badaniach tego typu (Koltyn, 1994; Koltyn, Schultes, 1997). Należy jednak wyraźnie podkreślić, że prezentowane $\mathrm{w}$ pracy dane stanowią jedynie wstępne wyniki uzyskane $\mathrm{w}$ badaniach pilotażowych projektu badawczego obejmującego liczniejszą grupę kobiet aktywnych fizycznie w czasie ciąży oraz dwie grupy kontrolne - kobiet uczestniczących w zajęciach relaksacyjnych oraz zajęciach szkoły rodzenia. Można mieć nadzieję, że analiza rezultatów tego badania pozwoli rozstrzygnąć przynajmniej niektóre kwestie podjęte w dyskusji.

Zgodnie z aktualnymi wskazaniami zdrowe kobiety ciężarne powinny podejmować systematyczną aktywność fizyczną o co najmniej umiarkowanej intensywności (Artal, O’T o ole, 2003; Royal College..., 2006). Jak wynika $\mathrm{z}$ prezentowanych $\mathrm{w}$ tej pracy oraz wcześniejszych badań (m. in. Gu s zk ow ska, B ernatek, 2010; Kolty n, 1994), już jednorazowe ćwiczenia fizyczne moga prowadzić do poprawy samopoczucia kobiet ciężarnych. Systematyczna aktywność fizyczna podczas ciąży może więc działać jako istotny czynnik profilaktyczny nie tylko wobec komplikacji natury zdrowotnej, ale także 
obniżający ryzyko zaburzeń afektywnych oraz podwyższający jakość życia kobiety ciężarnej (Parker, Smith, 2003; Poudevigne, O'Connor, 2006).

\section{Bibliografia}

Abraham A., Taylor A., Conti J. (2001), Postnatal depression, eating, exercise and vomiting before and during pregnancy, „International Journal of Eating Disorders”, 29, 482487.

Artal M., O'T oole M. (2003), Guidelines of the American College of Obstetricians and Gynecologists for exercise during pregnancy and the postpartum period, „British Journal of Sport Medicine", 37, 6-12.

Chou F. H., L in L. L., Cooney A. T., Walke r L. O., Rigg s M. W. (2003), Psychosocial factors related to nausea, vomiting, and fatigue in early pregnancy, „Journal of Nursing Scholarship", 35, 119-125.

D a C o st a D., L a ro u c he J., Drits a M., B re nde r W. (2000), Psychosocial correlates of prepartum and postpartum depressed mood, „Journal of Affective Disorders”, 59, 31-40.

D a C o s t a D., R i p p e n N., D r it s a M., R ing A. (2003), Self-reported leisure time physical activity during pregnancy and relationship to psychological well-being, ,Journal of Psychosomatic Obstetrics and Gynecology", 24, 111-119.

Davies G. A., Wolfe L. A., Mottola M. F., Mackinnon C. (2003), Exercise in pregnancy and postpartum periods, „Journal of Obstetrics and Gynecology Canada”, 25, $516-529$.

D u d e k B., Ko n i a r e k J. (1987), Adaptacja Testu D. M. McNaira, M. Lorra i L. F. Dropplemana - Profile of Mood States (POMS), „Przegląd Psychologiczny”, 3, 753-762.

D u d z i a k D. (2008), Aktywność ruchowa w czasie ciąży a lęk przed porodem, AWF, Warszawa, niepublikowana praca magisterska.

Evans J., Heron J., Francomb H., Oke S., Golding J. (2001), Cohort study of depressed mood during pregnancy and after childbirth, „British Medical Journal”, 323, 257-260.

F i eld T., D i e g o M., Hernandez-Re if M., S chanberg S., Kuhn C., Y ando R., $\mathrm{B}$ e $\mathrm{nde} 11$ D. (2003), Pregnancy anxiety and comorbid depression and anger: effect on fetus and neonate, „Depression and Anxiety”, 17, 140-151.

F l e m ing A. S., C orte r C. (1988), Factors influencing maternal responsiveness in humans: usefulness of an animal model, „Psychoneuroendocrinology”, 13, 189-212.

Goodwin A., A stbury J., Mc Me e ken J. (2000), Body image and psychological wellbeing in pregnancy: a comparison of exercisers and non-exercisers, „Australian and New Zealand Journal of Obstetrics and Gynaecology", 40, 443-447.

Go ry ń s k a E. (20005), Przymiotnikowa Skala Nastroju UMACL G. Matthews, A. G. Chamberlain, D. M. Jones. Podręcznik, Pracownia Testów Psychologicznych PTP, Warszawa.

G u s z k o w k a M. (2011), Physical activity in relation to affective states and labor anxiety in pregnant women, „Medicina Sportiva”, 15, 114-118.

G u s z k o w s k a M., B e r n a t e k P. (2010), Zmiany stanów emocjonalnych u kobiet ciężarnych po jednorazowych ćwiczeniach fizycznych, „Polskie Forum Psychologiczne”, 15, 14-24.

Guszkowska M., Dudziak D. (2008), Stany nastroju $i$ lęk przed porodem kobiet aktywnych i nieaktywnych ruchowo w czasie ciqży, [w:] M. K r a w c z y ń s k i (red.), Psychologiczne konteksty aktywności fizycznej człowieka, Ateneum - Szkoła Wyższa, Gdańsk, $57-69$. 
Josefsson A., Berg G., Nordin C., Sydsjo G. (2001), Prevalence of depressive symptoms in late pregnancy and postpartum, „Acta Obstetricia et Gynecologica Scandinavica", 80, 251-255.

Juczyński Z. (2001), Narzędzia pomiaru $w$ promocji $i$ psychologii zdrowia, Pracownia Testów Psychologicznych PTP, Warszawa.

Koltyn K. F. (1994), Mood changes in pregnant women following an exercise session and a prenatal information session, „Women's Health Issues”, 4, 191-195.

Kolty n K. F., S chultes S. S. (1997), Psychological effects of an aerobic exercise session and a rest session following pregnancy, „Journal of Sports Medicine and Physical Fitness”, 37, 287-291.

Koniak-Griffith D. (1994), Aerobic exercise, psychological well-being, and physical discomfort during adolescent pregnancy, „,Research in Nursing and Health”, 17, 253-263.

L e i f e r M. (1977), Psychological changes accompanying pregnancy and motherhood, „Genetic Sociology and Genetic Psychology Monographs", 95, 55-96.

L ox C. L., Treasure D. C. (2000), Changes in feeling states following aquatic exercise during pregnancy, ,Journal of Applied Social Psychology”, 30, 518-527.

Makowska Z., Merecz D. (2001), Polska Adaptacja Kwestionariuszy Ogólnego Stanu Zdrowia Davida Goldbergera: GHQ-12 I, GHQ-28, Instytut Medycyny Pracy, Łódź.

M o o r e D. S. (1978), The body image in pregnancy, ,Journal of Nurse Midwifery”, 22, 17-27.

O'H a r a M. W., N e u n a b e r D. J., Z e k o s k i E. M. (1984), Prospective study of postpartum depression: prevalence, course, and predictive factors, „Journal of Abnormal Psychology”, 93, 158-171.

P a r k e r K. M., S mith S. A. (2003), Aquatic-aerobic exercise as a means of stress reduction during pregnancy, ,Journal of Perinatal Education”, 12, 6-17.

Płaczkiewicz M. (2008), Rekreacja ruchowa a stany emocjonalne oraz obraz własnego ciała kobiet ciężarnych, AWF, Warszawa, niepublikowana praca magisterska.

P o u d e vi g n e M. S., O'C o n n or P. J. (2005), Physical activity and mood during pregnancy, „Medicine and Science in Sports and Exercise”, 37, 1374-1380.

Poudevigne M. S., O'C onnor P. J. (2006), A review of physical activity patterns in pregnant women and their relationships to psychological health, „Sports Medicine”, 36, $19-38$.

P ow e r T. G., P a rke R. D. (1984), Social network factors and the transition to parenthood, „Sex Roles”, 10, 949-972.

Royal College of Obstetricians and Gynaecologists (2006), Exercise in pregnancy, RCOG Statement, No. 4, http://www.rcog.org.uk/index.asp/PageID=1366.

S i p iń s k i A., P or ę b a R., C is ze k V. (1993), Psychologiczne aspekty w ostatnim okresie ciqży, [w:] Jakość narodzin. Jakość życia, IMiDz, Warszawa.

Stangert A., Cendrowska A., S zuki ewicz D. (2009), Kurs szkoty rodzenia jako sposób na obniżenie poziomu lęku przed porodem, „Family Medicine and Primary Care Review", 11, 53-59.

W a 11 a c e A. M., B o y e r D. B., D a n A., H o $1 \mathrm{~m} \mathrm{K.} \mathrm{(1986),} \mathrm{Aerobic} \mathrm{exercise,} \mathrm{maternal} \mathrm{self-}$ esteem and physical discomforts during pregnancy, „Journal of Nurse-Midwifery”, 31, $255-262$.

W r ze śn i e w s k i W., S o s n ow s k i T., M a t u s i k D. (2002), Inwentarz stanu i cechy lęku. Polska adaptacja STAI. Podręcznik, Pracownia Testów Psychologicznych PTP, Warszawa.

Zawadzki B., Strelau J., Szczepaniak P., Śliwińska M. (1998), Inwentarz Osobowości NEO-FFI Costy i McCrae. Adaptacja polska. Podręcznik, Pracownia Testów Psychologicznych PTP, Warszawa. 
Monika Guszkowska

\section{Determinants of emotional states in exercising pregnant women}

The aim of the study was to determine the effect of a single exercise session on mood states in pregnant women and to establish determinants of the effect size.

Subjects in the study were 25 pregnant women aged 22 to 36 years participating in a physical exercise program "Active Nine Months". The following tools were used: POMS, UMACL, STAI, GHQ-28, LOT-R, NEO-FFI; the Labor Anxiety Scale and personal questionnaire developed by the author.

A single session of physical exercise was followed by a significant improvement in the participants' mood states. The most salient determinant of mood improvement was trimester of pregnancy, allowing to predict the degree of decrease in state anxiety, anger and confusion. Labor anxiety was positively correlated with trait anxiety and economic status. The trimester of pregnancy and marital status were its predictors.

Systematic physical activity during pregnancy may act as an important factor decreasing the risk of affective disorders and enhancing pregnant women's quality of life.

Keywords: physical exercise, pregnancy, mood states, acute effect (aktywność ruchowa, ciąża, nastrój, efekt ostry). 